\title{
Paideusis
}

\section{Interests and Purposes in Conceptions of Autonomy}

\section{Jodi Lee Nickel}

Volume 16, Number 1, 2007

URI: https://id.erudit.org/iderudit/1072604ar

DOI: https://doi.org/10.7202/1072604ar

See table of contents

Publisher(s)

Canadian Philosophy of Education Society

ISSN

0838-4517 (print)

1916-0348 (digital)

Explore this journal

Cite this article

Nickel, J. (2007). Interests and Purposes in Conceptions of Autonomy. Paideusis, 16(1), 29-40. https://doi.org/10.7202/1072604ar

\section{Article abstract}

This article examines conceptions of autonomy outlined by Dearden, Callan, Dewey and Kerr and distinguishes between five conceptions, namely, belief autonomy, action autonomy, interest autonomy, purpose autonomy and social autonomy. While Kerr criticizes conceptions of autonomy which are not explicitly moral, this article argues that the emphasis in some philosophical literature has simply emphasized self-regarding virtues more than other-regarding virtues. Purpose autonomy is considered a rich conception of autonomy because it not only builds upon children's interests but provides the initiative and continuity to sustain interest even in challenging circumstances.
This document is protected by copyright law. Use of the services of Erudit (including reproduction) is subject to its terms and conditions, which can be viewed online.

https://apropos.erudit.org/en/users/policy-on-use/ 
Paideusis, Volume 16 (2007), No. 1, pp. 29-40

\title{
Interests and Purposes in Conceptions of Autonomy
}

\author{
JODI NICKEL \\ Mount Royal College, Canada
}

This article examines conceptions of autonomy outlined by Dearden, Callan, Dewey and Kerr and distinguishes between five conceptions, namely, belief autonomy, action autonomy, interest autonomy, purpose autonomy and social autonomy. While Kerr criticizes conceptions of autonomy which are not explicitly moral, this article argues that the emphasis in some philosophical literature has simply emphasized self-regarding virtues more than other-regarding virtues. Purpose autonomy is considered a rich conception of autonomy because it not only builds upon children's interests but also provides the initiative and continuity to sustain interest even in challenging circumstances.

\section{Introduction}

It is a truism amongst many philosophers of education that nurturing autonomy in young people is a central aim, if not the aim, of liberal democratic education (Callan1988; Dearden 1975; Gutmann 1999; Kerr 2002). However, it is by no means obvious what "autonomy" really means, and consequently, it is not obvious what schools and teachers are hoping to nurture. Etymologically, autonomy is straightforward: "auto" and "nomy" together refer to "self-rule" or self-government and this has applications in a variety of fields and disciplines (e.g., political autonomy of nations and professional autonomy of teachers). In education, autonomy has typically connoted freedom from external control. For example, children who are granted autonomy in a classroom setting are provided with the opportunity to choose what books to read, what stories to write and what games to play free from the teacher's control. We might refer to this conception of "autonomy" as a kind of negative freedom, a freedom from. In the philosophical literature, freedom from external constraint, also called negative freedom, is distinguished from positive freedom, or freedom to-freedom to do certain things or freedom for certain purposes. A thorough conception of autonomy needs to focus not just on the absence of external constraints but also upon some of the purposes to which freedom can be applied.

In this paper, I will examine conceptions of autonomy in the educational philosophy literature with a more particular focus upon "self-regarding virtues"- decisions about how one should live one's life. Kerr (2002) argues that some current conceptions of autonomy in educational philosophy describe a sort of freedom that would allow individuals to ignore their moral or social obligations to others. Morality involves two questions: "How shall I treat others?" and "How shall I live my life?" The former question involves other-regarding virtues and is often given priority in moral philosophy and education but the self-regarding virtues included in the second question are also important for a moral life. It is this question which primarily occupies the attention of the first three of four philosophers that

(C) Copyright 2007. Jodi Nickel assigns to Paideusis the right of first publication and educational and non-profit institutions a nonexclusive license to use this document for personal use and in courses of instruction provided that the article is used in full and this copyright statement is reproduced. Any other usage is probibited without the express permission of the author. 
I will examine, namely R.F. Dearden (1975), Eamonn Callan (1988), John Dewey (1938), and Donald Kerr (2002). I will explicate these leading conceptions of autonomy to draw out their key features and to show how these features make these conceptions, while similar, somewhat distinct.

\section{Conceptions of Autonomy}

\section{Dearden}

R.F. Dearden's (1975) paper Autonomy and Education has become one of the most widely read and cited pieces on the topic. His definition of autonomy is as follows:

A person is autonomous, then, to the degree that what he thinks and does in important areas of his life cannot be explained without reference to his own activity of mind. That is to say, the explanation of why he thinks and acts as he does in these areas must include a reference to his own choices, deliberations, decisions, reflections, judgments, plannings or reasonings. (p. 63, italics added)

Dearden is interested in what he calls "personal autonomy," a capacity that develops in degrees and may not necessarily be possessed by all adults. An agent who is personally or psychologically autonomous experiences a certain sense of freedom or liberty to develop her preferences and to pursue, so far as she is able, her interests or desires. By contrast, an individual who lacks psychological autonomy is someone whose beliefs and emotions (and by extension her actions) are outside the agent's direct control. Dearden illustrates this by supposing a delinquent youth, recently released from a "borstal institution," finds himself in the company of the wrong crowd. "If he 'must' accompany them in stealing a car because otherwise he would be called 'chicken,' then where is there any self-direction on his part in this state of freedom?" (p. 62).

Although Dearden starts out trying to explicate the difference between freedom and autonomy, he often resorts to describing something more like negative freedom or independence from constraint. For example, in praising the instrumental benefits of autonomy, he writes, "Even the youngest children enjoy 'doing it for themselves' and resent being 'bossed"' (p. 70). This sounds much like Erik Erikson (1963) who described how toddlers experience autonomy when they achieve a sense of independence and pride in their accomplishments. Erikson was clearly talking about a very different sort of autonomy than Dearden has defined. It is puzzling that Dearden would suggest these very young children who simply accomplish something without external constraint or assistance then possess the sort of rational autonomy (i.e., capacity to deliberate) that he defined.

Dearden seems willing to ascribe personal autonomy to the person whose beliefs are "his own," even if his beliefs are self-deceptive and immoral. "Kant wished to define autonomy in terms of selflegislated moral laws, but surely a criminal could present a fine example of autonomy in action" (p. 66). However, Dearden eventually admits that some kind of self-knowledge is a necessary condition for autonomy.

The better we know our motives, wishes, purposes, typical reactions to others and so on, then the greater is the possibility of bringing our thought and action under conscious control. But if the explanation of our thought and action lies in what are at present unconscious motives, then only true beliefs about them will create such a possibility of conscious control. (p. 66)

Thus, deliberation or judgment alone does not constitute autonomy. Self-control is also inadequate; as noted, criminals can be quite deliberative and self-controlled in carrying out their crimes. Agents must 
also grow in self-knowledge in order to be sure that their deliberation is leading them to right action rather than rationalizing away questionable actions.

To distinguish Dearden's autonomy from other conceptions, it may be helpful to apply some distinguishing tags: belief autonomy (BA) and action autonomy (AA). Notice that Dearden talks about what a person thinks and does so these are best regarded as two distinct aspects. A person is regarded as belief autonomous to the degree that what she thinks is explained by her own activity of mind (rather than indoctrination or manipulation) and she is regarded as action autonomous to the degree that what she does is explained by her own activity of mind.

For Dearden, belief autonomy will be enhanced by developing various "basic forms of understanding" through the school curriculum since these will form the basic criteria for judging our beliefs and activity of mind: "They contribute much to the background perspective from which choices, decisions, opinions and so on are made or formed in our society." (p. 72). In other words, students will be better able to assess the veracity of their beliefs by comparing them to the criteria that others have found useful in making their decisions and the perspectives that have formed our society. If my beliefs are explained by a blind acceptance of what my friends or teachers have told me, I lack belief autonomy.

Similarly, my actions must be explained by my own activity of mind, my "choices, deliberations, decisions, reflections, judgments, plannings or reasonings" (p. 63). Perhaps I act on impulse with no deliberation or foresight. Perhaps I timidly comply with demands because I am fearful of punishment but have given little attention to the legitimacy of these demands. Perhaps like the youth released from the borstal institution, I am influenced by peer pressure. In all these cases, I lack action autonomy. Belief and action autonomy are related since people often act upon their beliefs but they are still distinct. I can still hold personal beliefs even when my actions are constrained by another. Dearden's analysis demonstrates that the capacity to think and act independently surely support one's ability to live a good life; this leads to my assertion that Dearden is primarily interested in these aspects of autonomy that might be called self-regarding virtues.

\section{Callan}

Much like Dearden, Callan's (1988) conception of autonomy identifies the importance of "independence of mind" (p.26) and the "disciplined avoidance of self-deception" (p. 38), what Wood would label self-regarding virtues. But Callan's conception also centrally involves the students' interests, a term that is used in a particular way. Callan articulates how schools might promote autonomy, particularly by building upon children's current interests. Unlike the familiar use of this term which concerns what is in students' best interests (i.e., to their advantage), Callan uses the term interests to refer to those values and attitudes which give deep meaning and a sense of personal identity. He distinguishes between pursuing an interest and developing an interest in the following way. When children follow their interests, say, in finger painting, or computer games, or watching television, they are usually pursuing their interests. Students pursue these preferences but there is little evaluation of those enjoyments and little regard for how they might contribute to a good life. Developing an interest involves making a deep and positive value judgment about the preference and recognizing the way that interest enriches one's life. "The development of an interest implies a deepening understanding of its object, as well as a desire for understanding" (p. 62). ${ }^{1}$

In distinguishing between autonomy and the simple freedom to pursue one's interests (or preferences), Callan considers Mill's classic utilitarian argument that greater freedom leads to greater happiness. But if individuals choose badly and their choices make them unhappy, this utilitarian argument fails. "Where people are placed in circumstances where there is extensive freedom and hence

1 There are some similarities between what Callan calls an interest and MacIntyre's (1984) internal goods of a practice. 
the opportunity (as well as the burden) of creating meaning of their lives, their happiness is likely to be fragile at best if they have little realism or independence of mind" (Callan, 1988, p. 41). Admittedly, children's free choices may not benefit them so their choices must be limited in order to protect their future happiness and their "right to an open future" (Feinberg, 1980). In ethics, compulsion is typically justified if it prevents harm or promotes the good of the compelled. If we gave children the freedom to forego school or avoid challenging tasks, many would take the path of least resistance and would be less likely to benefit from policies that permitted greater freedom. Callan also notes that individuals' choices are not really free if they are not aware of the other options that are open to them or the consequences of the choices they are making. For Callan, the development of autonomy entails compelling children to broaden their "interests" so that they are better able to judge which preferences should become deep interests and so that they have more options to choose from as they work out their conception of a good life.

Next, Callan makes the distinction between activities that have immediate appeal and ones that might require some cultivation before one develops an interest. For example, it is possible for a child to have some interest in playing soccer even if she has never played the game simply because she has watched others play and recognizes that it could be enjoyable. However, she is less likely to be interested in mathematics unless she has actually participated in math activities. Does this mean that teachers are justified in coercing children towards activities that have little immediate appeal in hopes that they will develop interests in these? Callan admits that this is probably so with very young children and specializing too young may result in a loss of freedom because potential interests are left undeveloped. Compulsion will be necessary in early childhood because their interests are immature and their "education will be liable to degenerate into projects abandoned when they become too difficult and interests never pushed far enough to realize much of their value. . . What we have is a trade-off between the disvalue of a modest loss of freedom entailed by compulsion and a substantial gain which could not have been experienced without compulsion" (p. 114-115).

However, he believes there is a very serious loss of freedom if, in widening children's options, teachers fail to also develop children's existing interests.

The best policy is one that shows more respect for the child's current level of autonomy, and an interest-based curriculum is the one to be preferred by that criterion. Such a curriculum does not give students a license to do whatever they choose in the classroom, but it is systematically based on a regard for the child's evaluations. ... Insofar as we focus the curriculum upon the plethora of things the child is not now interested in to disclose all hidden aptitudes, we have correspondingly less opportunity to foster learning which opens up options by developing the children's present interests. (p. 76-77)

He argues that children must be permitted to make choices so they get some practice in acting upon their propensities and eventually making decisions about which interests are worth pursuing or not worth pursuing. Highly prescriptive state mandated curricula may work against the realization of Callan's interest-based ideals but inquiry based learning projects are promising possibilities.

Having attached the distinguishing tags of belief autonomy and action autonomy to Dearden's account, I shall also attach another, interest autonomy, to Callan's account. For Callan, autonomy is having the capacity to pursue one's interests and to judge those interests as valuable for one's conception of a good life. A related but stronger version of this ideal is explained by John Dewey (1938) though interestingly Dewey never actually uses the term autonomy. For Dewey, students should have the freedom to make many learning choices in the classroom but more importantly they should learn to "frame purposes, to evaluate desires by the consequences which will result from acting upon them; (and have) power to select and order means to carry chosen ends into operation" (p. 64). It seems Callan was also interested in Dewey's ideals, what I shall call purpose autonomy, because he argued that developing interests would involve evaluating those interests. But sometimes Callan's account seems 
shortsighted and focuses too heavily on children pursuing current interests. Without a long term view of what is best for them, it may be difficult for children to frame purposes and develop interests purposefully. Like Dearden, Callan emphasizes students' choices about how to make good lives for themselves rather than students' relationships with others, the other-regarding virtues.

\section{Dewey}

At first blush, Dewey's (1938) progressive education is likely to look much like interest autonomy, with students pursuing knowledge that is related to their experiences and desires or interests. However, Dewey places a much higher priority on purposes and takes pains to distinguish these from desires.

A genuine purpose always starts with an impulse.... Nevertheless neither impulse nor desire is itself a purpose. A purpose is an end-view. ... It is sound instinct which identifies freedom with power to frame purposes and to execute or carry into effect purposes so formed. (p. 67)

He explains purposes more fully:

A purpose differs from an original impulse and desire through its translation into a plan and method of action based upon foresight. ... Overemphasis upon activity as an end, instead of upon intelligent activity, leads to identification of freedom with immediate execution of impulses and desires. (p. 69)

Purpose autonomy seems to entail working towards desired ends, but doing so even when the work might entail acting against immediate desire. A child who genuinely wants to learn will often persevere through difficult tasks to advance her purposes.

Dewey argues that an effective progressive education, one that encourages "intelligent judgment," should operate on two key principles: continuity and interaction. Continuity distinguishes between educational experiences that are worthwhile and those that are not.

The continuity of experience may operate so as to leave a person arrested on a low plane of development, in a way which limits later capacity for growth. On the other hand, if an experience arouses curiosity, strengthens initiative, and sets up desires and purposes that are sufficiently intense to carry a person over dead places in the future, continuity works in a very different way. Every experience is a moving force. Its value can be judged only on the ground of what it moves toward and into. (Dewey, 1938, p. 37-38)

Miseducative experiences "(arrest) or (distort) the growth of future experience" (p. 25) by rendering students callous and unresponsive.

The second principle, interaction, refers to the interplay between external conditions or content and the internal conditions of the learner. Dewey complains that although traditional education provided experiences, there was little or no regard for what the learners brought to the learning situation.

The principle of interaction makes it clear that failure of adaptation of material to needs and capacities of individuals may cause an experience to be non-educative quite as much as the failure of an individual to adapt himself to the material. (p. 47)

Dewey admits that in a misinterpretation of progressive ideals, some teachers neglected content and advance planning believing it was "inherently hostile to the legitimate freedom of those being instructed" (p. 57). Instead, he recommends that the teachers play a key role in providing subject matter and content for learning experiences but the planning must be "flexible enough to permit free play for 
individuality of experience and yet firm enough to give direction towards continuous development of power" (p. 58). In following the principles of continuity and interaction, teachers create educative learning experiences that adapt to the interests and needs of the students with the aim not only of building upon the children's interests but also encouraging what I have called purpose autonomy, the development of initiative and power.

What makes Dewey's purpose autonomy more appealing than the previously elucidated belief, action, and interest autonomy is his emphasis on end-views-working towards one's purposes even when the work might entail acting against immediate desire. A child developing purpose autonomy may value perfecting a slap shot and will expend the necessary energy to improve rather than engage in the less taxing act of watching television. A child developing purpose autonomy may forego the pleasures of recess to develop a presentation on the abolition of child slavery because the project is meaningful and valuable to the child. Interests are fleeting and may only engage a child for a short time; purposes strengthen initiative and move the child forward into deeper and more meaningful experiences.

In this explication of Dewey's views, I have emphasized educative experiences and the freedom of the individual to pursue purposes. This freedom to choose one's purposes is related to the question, "How shall I live my life?"-an individual's personal pursuits. However, his earlier writings (1916) focused more upon the role of education in fostering the individual's capacity to contribute to a democratic society. While I have tried to show how purpose autonomy enriches the lives of individuals, I would argue that the enriched individual may well apply these purposes in causes or vocations that positively impact the individual's community.

\section{Kerr}

In a more recent exposition of autonomy, Donald Kerr (2002) criticizes Dearden's and Callan's conceptions for their absence of substantive moral commitment. He argues that both accounts are predicated on a notion of individuals separated from any community, social obligations or responsibilities. According to Kerr, the conceptions developed by Dearden and Callan are inappropriate because even an individual stranded on a deserted island can be considered autonomous provided she reasons, plans, and deliberates about her actions. Kerr argues, "The individual alone on an island is not bound by any moral rules since there is no one else present to whom she has to justify her decisions, or be honest to, or ensure her actions do not harm" (p. 22). If we could ascribe autonomy to such an individual without knowing how she would live morally in community with others, something is amiss. I have coined Kerr's conception of autonomy social autonomy because he believes autonomy is "best understood as describing a particular kind of relation between individuals and their community" (p. 15).

To better understand Kerr's criticisms of Dearden and Callan, perhaps it would be helpful to consider Rawls' (1993) distinction between the rational and the reasonable. Rawls argues that in a democratic society, persons should have two moral capacities: the capacity for being rational and the capacity for being reasonable. A reasonable person is interested in fair terms of reciprocity, justice and cooperation. In contrast, the rational person has the powers of judgment and deliberation in seeking her own ends. Rawls holds that being rational does not necessarily mean one is reasonable. He explains, "Merely reasonable agents would have no ends of their own they wanted to advance by fair cooperation; merely rational agents lack a sense of justice and fail to recognize the independent validity of the claims of others" (p. 52). It seems, then, that Kerr is accusing Dearden and Callan of emphasizing "the rational" to the exclusion of "the reasonable."

In defence of Dearden and Callan, while they seem to be talking primarily about how rational persons choose to make good lives for themselves, they would surely agree that a good life must include both wisdom in living one's own life as well as justice in relationships with others. Callan refers to autonomy as "central to the exercise of moral virtue" (p. 46), so, while not explicitly connected with responsibility to or for others, Callan's autonomous person is not simply concerned with self-interest. 
Admittedly, Dearden's view is even less explicitly moral than Callan's but he does recommend a good education that would encourage responsibility for one's actions, presumably responsibility to the moral community. Taking account of one's social obligations, whatever they might be, is part of making a good life for oneself. Dearden and Callan simply focused their writing on question two: "How shall I live my life?" more than upon question one: "How shall I treat others?" but as noted, both of these are important for living morally.

It is also important to note that Kerr worries that individualistic conceptions of autonomy (and he alleges Dearden and Callan's are too individualistic) fall prey to the criticisms of feminists and communitarians. These groups seem to believe that Kantian autonomy-the dominant modernist conception of autonomy-is too atomistic, too individualistic, too liberal (Friedman 2003; MacIntyre 1984). Feminists think that Kantian-liberal autonomy places too high an emphasis on self-sufficiency and includes a conception of persons devoid of caring relations. Kerr believes that Dearden's and Callan's conceptions of autonomy can be criticized on these grounds because the actors do not have to be accountable to the moral community. For Kerr, a defensible conception of autonomy must be moral, that is, must involve fair treatment of others. Communitarians claim that our values emerge in and from groups, traditions, and cultures making individuals mere reflections or representations of the communities of which each is a part (Kymlicka 1989). While individuals profess personal interests and preferences and claim to make and take responsibility for personal choices, communitarians remind us that such preferences and choices are far less autonomous and much more interdependent than liberals would like to believe. Kerr agrees that actors have to be accountable to the community but denies the determinism that he believes underlies communitarianism; people are embedded in and influenced by their social context but they are also capable of authorizing or rejecting social norms as they reflect on their own values. Furthermore, their choices are not made in a void but should be with reference to certain criteria that inform their decisions, that is, the criteria of the moral community, their own consciences and their obligations to others. The capacity to reflect upon one's values and give laws to oneself is a key aspect of exercising moral autonomy as Kerr notes.

After criticizing Dearden and Callan's conceptions, Kerr endorses Kenneth Strike's (1982) account which focuses on human beings' moral responsibility to the community and uses phrases that sound distinctly Kantian and Rawlsian:

Human beings are ends in themselves, and are moral agents who are responsible to choose wisely on their own behalf and act justly with respect to others. They are morally responsible for what they choose and what they do.... A moral agent who is responsible for his choices must demand both the opportunity and the resources to choose wisely. (p. 19)

More than just external freedom, a morally autonomous person must respect the rights of others and principles of equality. We must have the freedom to make decisions about our lives but we should also have enough information to make decisions and the ability to judge that information reasonably. The onus is therefore upon educators to provide guidance so that children become rational people who can deliberate about what is in their own best interests and reasonable people who can recognize and respect others and their rights. ${ }^{2}$

\footnotetext{
2 A further point of clarification is necessary concerning the importance of morality for autonomy. Of Kantian morality, Wood (1999) writes, "If I am a decent person, I will choose to give my life meaning by pursuing some set of ends that fall under the general descriptions 'my own perfection' and 'the happiness of others"' (p. 329). Here Wood considers "my own perfection" to be those decisions I make concerning how I will live my life (as a weightlifter, a musician, a scientist or poet). "The happiness of others" includes other-regarding virtues - life pursuits that commit me to the good of others. But if I choose to advance my own perfection in ways that are immoral and disrespectful to others, these projects are "ultimately contrary to reason" (Wood, p. 329) because they are contrary to morality. Wood cautions that these duties are wide so "I never deserve blame for aiming at less good rather than more or even for being less devoted to good ends than I might have been" (p. 329).
} 
I support Kerr's conception of autonomy. However, I maintain that his criticisms of Dearden and Callan's conceptions are unwarranted because moral relations with others simply was not the topic they chose to write about. They chose to write about the individual's pursuit of a good life. That they seldom explicitly addressed other-regarding virtues does not mean that they regarded these as unimportant, only that they fell outside the scope of their discussions.

\section{Five Conceptions of Autonomy}

It should now be clear that any philosophical definition of autonomy will involve much more than independence from external control. Autonomy is central to responsible action and creating a good life for oneself. Having considered the preceding accounts of autonomy, I shall highlight the elements that seem most helpful in articulating a conceptual framework.

I have proposed that Dearden (1975) is interested in belief autonomy (BA) and action autonomy (AA) - that students think and act by "(their) own activity of mind" (p. 60). He considers students to be more autonomous if they are acting according to their own beliefs and teachers contribute to this autonomy by helping students to reason more effectively and reflect upon the quality of their own ideas. He rightly notes that school tasks such as personal writing, drama, and discussion may well contribute to greater independence of mind, key to autonomous beliefs and actions.

Callan (1988) argues that children need to be exposed to many options so that their interests are broadened and they choose with as much knowledge as possible. Recall that interests are those pursuits that give a person a sense of meaning and identity. A curriculum that promotes interest autonomy (IA) must build upon and develop children's current interests and provide them with plenty of opportunities to exercise their burgeoning capacity to make decisions about what is most valuable. Callan's interest autonomy, focuses upon how the children are freed to pursue their interests but he wants students to eventually make strong evaluations about which of these interests is not only interesting (i.e., enjoyable) but will further their chosen goals. This stronger evaluation of one's purposes is less prominent in Callan's account; he focuses much more upon children's present interests rather than what might be in their longer term interests.

Dewey's account more coherently characterizes purpose autonomy (PA). His account goes beyond immediate desires to acting with foresight. His progressive education is based upon the experiences and interests of the learner, but truly educative experiences also promote future learning. An education that promotes purpose autonomy "arouses curiosity, strengthens initiative, and sets up desires and purposes" (p. 38) and moves the learner forward into future learning experiences. A learner with purpose autonomy is more willing to persist with challenging tasks because they further her chosen ends.

Kerr's social autonomy (SA) reminds us that self-regarding virtues, while valuable, must also be accompanied by other-regarding virtues. Becoming more autonomous means not only developing the capacity to thoughtfully pursue one's interests but also doing so while also attending to the impact of one's actions upon others.

In an effort to clarify the meaning of these various conceptions of autonomy, let us consider some clear examples when teachers may encourage student autonomy, examples when they discourage student autonomy, and examples when they appear to be undermining autonomy but are legitimately curtailing students' freedom. Each list includes examples relevant to belief autonomy (BA), action autonomy (AA), interest autonomy (IA), purpose autonomy (PA), and social autonomy (SA). ${ }^{3}$

\footnotetext{
${ }^{3}$ I have chosen to list examples of belief autonomy and action autonomy together because these capacities are so closely related. Belief autonomy is a necessary condition for action autonomy because one cannot act autonomously without belief autonomy; that is, one's actions cannot be explained by one's own activity of mind
} 
Examples of cases in which teachers clearly encourage autonomy are:

1. BA/AA: When teachers "give reasons (and draw) attention to the basis on which people can determine for themselves what to think and to do" (Dearden 1975, p. 74), students are increasingly able to direct themselves and give reasons for their choices. Furthermore, through curricular material teachers can help children "develop capacities for criticism, rational argument, and decision-making by being taught how to think logically, to argue coherently and fairly, and to consider the relevant alternatives before coming to conclusions" (Gutmann 1999, p. 50). For example, a teacher encourages BA when she urges students to explain how they arrived at their conclusions and encourages AA when she expects students to explain their actions.

2. IA: When teachers afford "ample scope for variation in curricula according to the bent of the individual's interests" (Callan 1988, p. 69) such as in choosing writing topics, reading materials and the focus of their science projects, students develop interests and desire greater understanding.

3. PA: Dewey says, "If an experience arouses curiosity, strengthens initiative, and sets up desires and purposes that are sufficiently intense to carry a person over dead places in the future" (p. 38), children are more apt to persevere with difficult tasks because doing so will help them to achieve some objective they value. When teachers help children to not only do what they enjoy but to set up purposes they value, children begin to develop purpose autonomy. Examples might include inquiry projects that lead children to social action or writing endeavours that are personally stimulating to the authors or appreciated by an audience.

4. SA: When teachers help children to empathize with others, children may begin to respect others' rights and feelings and respond out of moral or social obligation to others.

The following is a list of cases when autonomy could be undermined.

1. BA/AA: When teachers insist upon compliance with arbitrary demands or upon a correct way to do tasks with little flexibility or rationale, particularly when reasons could have easily been given, children are not led to reason for themselves or to act according to their own beliefs.

2. IA: When teachers disregard children's current interests when they could have been reasonably incorporated, children's engagement and commitment to learning wane.

3. PA: When teachers impose learning tasks upon the students even when the children have well developed interests they could legitimately pursue (e.g., little opportunity for self-chosen reading materials or writing topics) or when teachers assign rote tasks without offering a rationale, purpose autonomy is undermined.

4. SA: Regularly requiring compliance with moral directives ("Take turns") without explaining the moral significance of the expectation may lead students to obedience but not necessarily respect for others.

However, there are many cases where teachers legitimately curtail students' freedom. In these cases, it may appear that they are undermining autonomy, but their actions are important for other goals of schooling and for children's future autonomy.

unless one's beliefs are also explained by one's activity of mind. However, it is possible to possess belief autonomy even when one's actions are constrained so the distinction is still warranted. 
1. BA/AA: Teachers may sometimes require compliance without offering explicit rationale for every single directive because to do so would become tedious and they expect children to tacitly understand the expectations and their importance for teaching and learning.

2. IA: Teachers frequently introduce children to content which is seemingly irrelevant to them because (there are undoubtedly other reasons as well):

- the curriculum requires that students be introduced to certain basic concepts,

- teachers hope to pique curiosity and joy in learning,

- children may develop an interest in or aptitude for the new concept or skill, and

- they want students to learn to reason effectively and this skill may be acquired through the curricular tasks (e.g., mathematical problem-solving).

3. PA: Teachers often expect students to persevere with tasks that seem not to fit with the purposes children currently have because teachers recognize the value these have for them in the long term. Learning to read is simply not a negotiable task, despite the children's current frustration! Effective teachers endeavour, of course, to help children overcome this frustration and recognize the value and enjoyment to be found in reading.

4. SA: Teachers may sometimes compel students to act kindly or apologize to those they have wronged even when the students are not motivated to do so because they wish to communicate the importance of fundamentals in the classroom community that students may later understand.

This list of examples is not exhaustive but demonstrates how teachers may (perhaps unintentionally) encourage autonomy, discourage autonomy and legitimately limit freedom to promote future autonomy.

These cases could perhaps be better illustrated with an example. Josh (a pseudonym for a boy I met during research in his classroom) is an eight-year-old boy who genuinely enjoys and excels at math. He has learned that he might one day apply these skills as an engineer and make a good salary. He believes this because teachers and parents have explained this to him so he believes it on good authority and with good reason (belief autonomy). He has action autonomy because his actions, avidly participating in math tasks, are explained by his own decisions. He has interest autonomy because he is able to pursue his interest in math and finds intrinsic value in it. However, if he truly wants to be an engineer or live a good life in some other meaningful and interesting pursuit, he may have to do activities that are not now interesting or intrinsically valuable to him in order to achieve his goal (purpose autonomy). For example, if he fails to learn to read and write effectively, this lack will interfere with his ability to be an engineer and succeed in university. Failure to get along with others may also interfere with a good life for Josh since his career as an engineer is not the only thing necessary for his happiness; acceptance and friendship are also likely to enrich his life (social autonomy). (In actual fact, Josh does struggle with literacy tasks and is often unkind to others). So despite acting according to his own beliefs and his own interests, if he lacks purpose autonomy, he will not be able to order his life in ways that will help him to achieve his purposes. His teacher endeavours to cultivate purpose autonomy by helping him to deliberate about the ends he desires and to do what is necessary, even if it is not immediately desirable, to achieve those purposes.

In my experience, Josh and many other children often seem to find school tedious and complete teacher assigned tasks begrudgingly or not at all. To encourage children's growth in purpose autonomy, teachers must provide more opportunities for children to direct their learning towards their deep interests, those pursuits that animate them and give richness to their lives. While governments typically set mandated curricula and these are important for exposing children to the knowledge of the world, there needs to be as many opportunities as possible, albeit guided opportunities, for children to direct their learning towards those areas of study that they find deeply engaging. Furthermore, the purpose of 
learning tasks needs to be continually emphasized. Children may be marched through math exercises, historical facts, science experiments, and writing exercises with little understanding of their educational purpose. An educative learning experience that develops interest and purpose autonomy: "arouses curiosity, strengthens initiative, and sets up desires and purposes" (Dewey 1938, p. 38). I would argue that an "inquiry approach" to learning where children are guided in seeking out answers to their own questions might help achieve this goal (Short et al 1996).

Quite apart from finding purpose in academics or some other meaningful pursuit, children's ability to be autonomous and to live good lives may be limited by the manipulation of the media and peer groups who dictate what is desirable, especially outside of school. Character educators such as Lickona (1997) might recommend the explicit promotion of virtues such as courage and confidence to withstand these pressures. While I have no quarrel with such recommendations, I would argue that an individual who is growing in purpose autonomy is also growing in courage and confidence. Dewey (1938) argued for developing "purposes that are sufficiently intense to carry a person over dead places in the future" (p. 38). Perhaps these purposes may also carry children over challenging places, places where other impulses and desires compete for attention. Children who are developing a strong sense of identity based upon their strengths and passions, dare I say purposes, are less susceptible to the influences that run contrary to their values. Research suggests that those who find meaningful pursuits are in fact resilient -- less susceptible to the challenges that come their way (Werner \& Smith, 1982).

In conclusion, social autonomy is a term I use to characterize Kerr's conception of autonomy which is particularly interested in other-regarding virtues related to autonomy (moral action in relationships with others). Belief, action, interest and purpose autonomy are more heavily focused upon self-regarding virtues - how one should live one's life. Of this latter group, I consider purpose autonomy to be the richest because it not only builds upon children's choices but provides the initiative and continuity to sustain engagement even in challenging circumstances. Promoting purpose autonomy is a high calling for teachers of young children but is surely a goal worth striving for.

\section{References}

Callan, E. (1988). Autonomy and schooling. Kingston and Montreal: McGill-Queen's University Press.

Dearden, R. F. (1975). Autonomy and education. In R. F. Dearden, P. H. Hirst, \& R. S. Peters (Eds.). Education and reason: Part 3 of Education and the Development of Reason (p.58-75). London: Routledge and Kegan Paul.

Dewey, J. (1916/1985). Democracy and Education. Carbondale, IL: Southern Illinois University Press.

Dewey, J. (1938). Experience and education. New York: Collier Books.

Erikson, E. (1963). Childhood and society (2nd ed.). New York: Norton.

Feinberg, J. (1980). The child's right to an open future. In W. Aiken \& H. LaFollette (Eds.). Whose child?: Children's rights, parental authority, and state power. Totowa, New Jersey: Rowman and Littlefield.

Friedman, M. (2003). Autonomy, gender, and politics. New York: Oxford University Press.

Gutmann, A. (1999). Democratic education (Second ed.). Princeton, NJ: Princeton University Press.

Kerr, D. (2002). Devoid of community: Examining conceptions of autonomy in education. Educational Theory, 52(1), 13-25.

Kymlicka, W. (1989). Liberalism, community and culture. Oxford, UK: Clarendon Press.

Lickona, T. (1997). Educating for character: A comprehensive approach. In A. Molnar (Ed.). The construction of children's character: Ninety-sixth yearbook of the National Society for the Study of Education, Part II (pp. 45-62). Chicago, IL: The University of Chicago Press.

MacIntyre, A. C. (1984). After virtue: A study in moral theory. Notre Dame, IN: University of Notre Dame Press.

Rawls, J. (1993). Political liberalism. New York: Columbia University Press. 
Short, K., Schroeder, J., Laird, J., Kauffman, G., Ferguson, M. \& Crawford, K. (1996). Learning together through inquiry: From Columbus to integrated curriculum. York, Maine: Stenhouse.

Strike, K. (1982). Liberty and learning. Oxford: Robertson. Quoted in D. Kerr, Devoid of community: Examining conceptions of autonomy in education, Educational Theory 52(1), 19.

Werner, E. E., and Smith, R. S. (1982). Vulnerable but invincible: A longitudinal study of resilient children and youth. New York: McGraw-Hill.

Wood, A. W. (1999). Kant's ethical thought. Cambridge, UK: Cambridge University Press.

\section{About the Author}

Dr. Jodi Nickel teaches in the Department of Child and Youth Studies at Mount Royal College, Calgary, Alberta. jnickel@mtroyal.ca 